\title{
Influence of crop and tillage on mites and springtails in arable soil
}

\author{
C. F. van de Bund
}

Plant Protection Service, Wageningen, the Netherlands

Received: 21 September 1970

\begin{abstract}
Summary
Under the influence of crop and soil the composition of the soil fauna may vary considerably. However the frequency of some species under a particular crop differed between soil types.

Tillage, in particular, affects the vertical distribution of the springtail and mite populations. In uncultivated soil almost all the springtails and mites occurred in the top $5 \mathrm{~cm}$. In normally tilled soil the soil fauna was more evenly distributed in the top soil. Small cylinders inserted into the soil, in which leaf discs were enclosed in coarse and in fine sand, showed considerable differences in the composition of the soil fauna present. Most likely, mites and springtails are especially affected by the soil structure, the moisture condition and the microflora present, which is also determined by the crop grown in this soil.
\end{abstract}

\section{Introduction}

Mites and springtails are very numerous in soil. A litre of soil normally contains $500-1000$ of these animals.

When conditions are very suitable, this number may be considerably higher. Most springtails and mites live in decaying organic matter. Except for the Protozoa and the Nematoda, the Acari and the Collembola are the most abundant animals in soil. At an estimate, there are about 300 species of Collembola and 1600 species of Acari in the Netherlands. About 80 species of mites and 18 species of springtails are found frequently in arable soil. Springtails and most of the soil-inhabiting mites feed on decaying organic matter, bacteria, fungi and algae. Some species feed on parts of living 'higher' plants under special conditions. A large group of mites, specially the Gamasides, are predators, which prey on mites, springtails, small insect larvae and nematodes. Collembola and Acari occur very frequently in many species in a great number of habitats. Many species can be found anywhere in most soils. Thus this group of animals may be used as indicators of special conditions that may occur in the soil like, structure, humidity, content of organic matter, plant cover, presence of waste products and pesticides. It is the value as indicator in which we are interested. For this reason we investigate arable soil at different localities and under different plant cover. The data we obtained on field plots are interesting, but these are not yet enough to draw final conclusions. 


\section{Methods}

Soil samples were taken with a soil sampler with a diameter of $5.7 \mathrm{~cm}$ at the mouth; $5 \mathrm{~cm}$ above the mouth the sampler is $0.5 \mathrm{~cm}$ wider. This prevents the core of soil from compressing during sampling. The sampler has a length of $20 \mathrm{~cm}$. The soil sample is removed by a rod just fitting in the sampler. For analysis the cores were divided by cutting the parts representing the depths needed for investigation. The separated parts of the cores were placed into an aluminium cylinder with a perforated bottom. These perforations have a diameter of $1.5 \mathrm{~mm}$. The diameter of the cylinders is $5.7 \mathrm{~cm}$ and the height is $2.5 \mathrm{~cm}$. The filled cylinders were attached to chromed copper vials of identical diameter. These vials were filled with a little tap water and placed in a tank with running tap water. From above the samples were heated by 16 electric bulbs of $40 \mathrm{~W}$. These lamps were placed in such a way that the surface of the samples attained a maximum temperature of about $35^{\circ} \mathrm{C}$ when the soil had dried. The running water had an average temperature of $10^{\circ} \mathrm{C}$. This method is derived from the high-gradient cylinder method of McFadyen. By this method the soil samples dry slowly and attain a high temperature when the soil sample is completely dry. The drying is done from the top layer to the bottom part. This agrees with the normal conditions outdoors when the sun is shining. The samples are dry after 5-7 days. Under these conditions the slowly moving and delicate specimens will have the opportunity to leave the soil sample. Because of the low temperature of the tap water, the animals caught are nearly all alive when the drying process is completed. All Collembola and Acarina were collected after drying. All specimens were prepared, counted and identified. For this purpose the catch was poured into a petri dish and the vial was thoroughly rinsed with $96 \%$ alcohol. The alcohol used for rinsing was also poured into the petri dish. After this some $96 \%$ alcohol was added to make the mixture about 3 parts alcohol and 2 parts water. After some days the mites and springtails were transferred with a micro-needle with a small loop into a cavity-slide filled with lactic acid. These slides were closed with a cover-glass. After storing at room temperature for two or three weeks, the mites and springtails were suitable for microscopic identification.

\section{The influence of soil type and crop on the soil fauna}

Experimental plots are arranged at different places in the Netherlands to study the interrelations of crop and nematodes under influence of crop rotation. In these fields are also plots in which the same crop is grown as a 'monoculture' for 5-9 years in succession. These plots are very suitable to study the influence of plant species on the soil fauna. The investigations are carried out at the localities given in Table 1.

From these experimental fields the 'monoculture' plots with Tagetes, potatoes, a mixture of perennial ryegrass and white clover, sugarbeet, oats and fallow were investi-

Table 1 Average number of mites and springtails per $1000 \mathrm{ml}$ of arable soil

\begin{tabular}{llrr}
\hline Place & \multicolumn{1}{c}{ Type of soil } & Mites & Springtails \\
& & & \\
Hagestein & heavy clay with $60 \%$ silt & 154 & 125 \\
Wageningen & light sandy soil with $3 \%$ humus & 171 & 193 \\
Ellecom & sandy soil with a low content of loess & 184 & 290 \\
Emmercompascuum & peaty soil & & 345
\end{tabular}


C. F. VAN DE BUND

Table 2 Average number of the most common mites and springtails per $1000 \mathrm{ml}$ of arable soil

\begin{tabular}{lcccc}
\hline & Wageningen & Ellecom & Emmercompascuum & Hagestein \\
Variatipes quadrangularis Paoli & 20 & 21 & 35 & - \\
Tectocepheus velatus (Mich.) & - & 3 & 18 & 13 \\
Rhodacarus roseus Oudemans s.1. & 33 & 49 & 4 & + \\
Onychiurus armatus (Tullb.) & 11 & 92 & 26 & 13 \\
Tullbergia krausbaueri (Börner) & 150 & 181 & 225 & 4 \\
\hline
\end{tabular}

gated. It turned out that the number of animals showed considerable differences in the different soil types. The number of springtails and mites in the heavy clay was notably smaller than those in sandy and peat soil. The number of recovered species showed little differences. However the presence of the observed species showed obvious differences (Table 2). The samples of the heavy clay showed the greatest dif-

Table 3 Number of mites and springtails per $1000 \mathrm{ml}$ of soil $(8$ cores of $125 \mathrm{ml}$ ) of experimental plots in which the same crop is grown for 5-9 years in succession. (In parentheses the number of cores in which the animals are found)

Place Potato $\begin{gathered}\text { Mixture of } \\ \text { grass and } \\ \text { white clover }\end{gathered}$ Tagetes Beet $\quad$ Oats $\quad$ Fallow

A. Variatipes quadrangularis Paoli

$\begin{array}{llr}\text { Wageningen } & 0 & 76(6) \\ \text { Ellecom } & 0 & 93(7) \\ \text { Emmercompascuum } & 0 & 13(6) \\ \text { Hagestein } & 0 & 0\end{array}$

$\begin{aligned} 48 & (5) \\ 0 & \\ 30 & (7) \\ 0 & \end{aligned}$

0
0
0
0

$\begin{array}{rrr}0 & 0 \\ 32 & (6) & 0 \\ 131 & (8) & - \\ 0 & & 0\end{array}$

B. Tectocepheus velatus (Mich.)

$\begin{array}{lc}\text { Wageningen } & 0 \\ \text { Ellecom } & 0 \\ \text { Emmercompascuum } & 26(8) \\ \text { Hagestein } & 14(6) \\ \text { C. Rhodacarus roseus } & \text { Oudemans s.l. }\end{array}$

$\begin{array}{lc}\text { Wageningen } & 14(6) \\ \text { Ellecom } & 0 \\ \text { Emmercompascuum } & 14(7) \\ \text { Hagestein } & 0 \\ \text { D. Onychiurus armatus (Tullb.) }\end{array}$

$\begin{array}{lrrrrrr}\text { Wageningen } & 0 & 18(5) & 48(7) & 0 & 0 & 0 \\ \text { Ellecom } & 198(8) & 29(8) & 24(7) & 63(8) & 231(8) & 9(5) \\ \text { Emmercompascuum } & 20(5) & 39(7) & 14(8) & 20(5) & 36(8) & - \\ \text { Hagestein } & 60(8) & 16(6) & 0 & 0 & 0 & 0\end{array}$

E. Tullbergia krausbaueri (Börner)

$\begin{array}{lrrrrrrr}\text { Wageningen } & 61(7) & 315(8) & 297(8) & 36(6) & 161(8) & 27(6) \\ \text { Ellecom } & 208(8) & 342(8) & 88(8) & 214(8) & 202(8) & 36(7) \\ \text { Emmercompascuum } & 190(8) & 156(4) & 216(4) & 561(8) & 0 & - \\ \text { Hagestein } & 0 & 0 & 0 & 0 & 25(5) & 0\end{array}$


ferences. The Oribatei were present in far greater number, whereas the springtail family, the Onychiuridae, were relatively scarce. The Oribatei were also more abundant in the peaty soil than in the sandy soil. The greatest number of springtails, specially the Onychiuridae, were found in the sandy soil containing some loess. The predacious mite, Rhodacarus roseus Oudemans s.l., was most abundant in the same sandy soils (Table 2).

Euedaphic species like the Onychiuridae and Rhodacarus roseus are probably restricted in their movement by the compactness of the heavy clay, which may be a cause of their relative scarceness in that type of soil.

The investigated crops showed a considerable influence on the fauna of mites and springtails. However the preference for living under a special crop was not similar in the different types of soil (Table 3). As an example the springtail Onychiurus armatus was most abundant under potatoes in heavy clay, but in sandy soil it was most abundant under Tagetes, in sandy soil containing some loess it was mostly found under potatoes and oats. This springtail showed no clear preference to occur under special crops in peaty soil, it showed a more random distribution throughout the field plot (Table 3D).

It was obvious that the number of mites and springtails was much greater within the root system of the plants than in bare soil of the fallow plots. Also in stable manure or in plant litter like straw, inserted into the soil, large aggregations of mites and springtails occurred (Tables 4 and 5).

\section{The influence of tillage on the soil fauna}

Tillage has a great effect on the distribution of springtails and mites in the soil. They occur most abundantly in the top $3 \mathrm{~cm}$ of uncultivated soil and grasslands. Most of the decaying plant litter is present in that part of the soil. Downwards the soil becomes more compact and contains less organic matter. This is in agreement with the distribution of the mites and springtails which prefer the presence of organic matter. In tilled arable soil, organic matter is more evenly distributed in the top soil, and so are the springtails and mites.

Table 4 Average number of springtails and mites per $100 \mathrm{ml}$ soil (nematodes per $100 \mathrm{~g}$ soil) of a field plot under carrots at Wageningen, autumn 1966

With stable manure

Collembola

Acari

Phytophagous nematodes

Saprophagous nematodes
Without stable manure

$\begin{array}{cr}74 & 18.5 \\ 30.5 & 4.4 \\ 913 & 1459 \\ 23999 & 4882\end{array}$

Table 5 Average number of springtails and mites recovered per $100 \mathrm{~g}$ air-dried wheat straw inserted in arable sandy soil and per $100 \mathrm{~g}$ air-dried soil obtained from the near surroundings of the inserted packets of wheat straw

\begin{tabular}{lrr}
\hline & Soil & Straw \\
Collembola & 9.4 & 880 \\
Acari & 24.6 & 2620 \\
\hline
\end{tabular}


Observations were made in experimental field plots at Achterberg (Province of Utrecht) on light sandy soil which had not been tilled for many years. Crop growing was possible by the use of weedkillers for normal weed control and for the removal of (remaining) superfluous green parts of the crops. All dead organic matter remained on the field. Sowing and planting of the crop was carried out in the remaining litter. The check plot received the same weedkillers for regular weed control, but here no use was made of weedkillers, like paraquat, for the control and removal of remaining crop vegetation.

The field plots were $500 \mathrm{~m}^{2}$ on which spring wheat was grown in 1969 and carrots in 1970. The structure of the soil and the rooting of some crops on the field IBS 820 are described by Bakermans and de Wit (1970; Fig. 26, 27, 28 and 29).

Eight soil samples were taken from each plot in March 1969. From these soil samples the layers of $0-2.5 \mathrm{~cm}, 2.5-5 \mathrm{~cm}$ and $10-12.5 \mathrm{~cm}$ below the surface of each core were investigated. Six soil samples were taken from each of both plots on 21 May 1970. From these soil samples the soil layers of $2.5-5 \mathrm{~cm}, 7.5-10 \mathrm{~cm}, 15-17.5 \mathrm{~cm}$ and $25-27.5 \mathrm{~cm}$ below the surface were investigated. The layer of $25-27.5 \mathrm{~cm}$ represented the layer just below the top soil of the control field.

It turned out that the number of recovered animals showed little difference from both plots. The number of species differed considerably. The number of Collembola and Acarina species was greater in the check plots in both years (Table 6). Striking was the relatively low number of individuals of prostigmatic mites in the zero-tillage plot. Of more importance was the difference of the vertical distribution pattern (Table 7 and 8 ). Most springtails and mites were found in the layer of $0-5 \mathrm{~cm}$ under the surface of the soil in the zero-tillage plots. The majority of the springtails and mites of the control plot was recovered from the lower part of the topsoil : $10-12.5 \mathrm{~cm}$ and $15-17.5 \mathrm{~cm}$, respectively, below the surface in both years. The number of mites and

Table 6 Average number of mites and springtails per $1500 \mathrm{ml}$ arable soil from Achterberg (Utrecht)

\begin{tabular}{|c|c|c|c|c|c|c|c|c|}
\hline & \multicolumn{2}{|c|}{ Tillage 1969} & \multicolumn{2}{|c|}{ Tillage 1970} & \multicolumn{2}{|c|}{ Zero-tillage 1969} & \multicolumn{2}{|c|}{ Zero-tillage 1970} \\
\hline & $\begin{array}{c}\text { indi- } \\
\text { viduals }\end{array}$ & species & $\begin{array}{c}\text { indi- } \\
\text { viduals }\end{array}$ & species & $\begin{array}{c}\text { indi. } \\
\text { viduals }\end{array}$ & species & $\begin{array}{c}\text { indi- } \\
\text { viduals }\end{array}$ & species \\
\hline Acari & 56 & 12 & 189 & 16 & 30 & 9 & 79 & 12 \\
\hline Collembola & 239 & 10 & 321 & 11 & 222 & 6 & 356 & 5 \\
\hline
\end{tabular}

Table 7 Vertical distribution of mites and springtails in arable soil from Achterberg, March 1969. Each depth is represented by $500 \mathrm{ml}$ of soil

\begin{tabular}{lccc}
\hline & $\begin{array}{c}0-2.5 \mathrm{~cm} \\
\text { below surface }\end{array}$ & $2.5-5 \mathrm{~cm}$ & $12.5-15 \mathrm{~cm}$ \\
Tilled soil & & & \\
$\quad$ Mites & 4 & 10 & 42 \\
$\quad$ Springtails & 34 & 66 & 139 \\
Untilled soil & & & 7 \\
$\quad$ Mites & 14 & 9 & 62 \\
Springtails & 46 & 114 & 7 \\
\hline
\end{tabular}


Table 8 Vertical distribution of mites and springtails in arable soil from Achterberg, May 1970. Each depth is represented by $375 \mathrm{ml}$ of soil

\begin{tabular}{|c|c|c|c|c|}
\hline & $\begin{array}{c}2.5-5 \mathrm{~cm} \\
\text { below surface }\end{array}$ & $7.5-10 \mathrm{~cm}$ & $15-17.5 \mathrm{~cm}$ & $25-27.5 \mathrm{~cm}$ \\
\hline \multicolumn{5}{|l|}{ Tilled soil } \\
\hline Mites & 34 & 21 & 99 & 35 \\
\hline Springtails & 41 & 26 & 224 & 30 \\
\hline \multicolumn{5}{|l|}{ Untilled soil } \\
\hline Mites & 38 & 17 & 15 & 9 \\
\hline Springtails & 208 & 109 & 32 & 7 \\
\hline
\end{tabular}

springtails under the topsoil, $25-27.5 \mathrm{~cm}$ below the surface, was also considerably greater in the control plot.

To investigate the influence of soil structure on the soil fauna small discs of dead apple leaves, all picked from the same tree just before they were shed, were enclosed in sterile sand. Two fraction sizes of sand were compared, coarse sand of 1-2 mm and very fine sand of particles $<0.2 \mathrm{~mm}$. Small aluminium cylinders with a diameter of $57 \mathrm{~mm}$ and a height of $25 \mathrm{~mm}$ were half filled with sand. On top of this sand a disc of apple leaf of a diameter of $32 \mathrm{~mm}$ was placed, and the leaf disc was covered with sand until the whole cylinder was filled. The top of the cylinder was open, at 4 places in the wall a $1 \mathrm{~cm}$ hole was drilled. The bottom was an aluminium plate provided with 4 holes of $4 \mathrm{~mm}$ diameter. These holes and the open topside ensured vertical and horizontal entrance into the content of the cylinder. The cylinders were packed in small nylon gauze bags with a mesh width of $1 \mathrm{~mm}$ to prevent entrance of earthworms. They were inserted into the soil of the experimental plot $5 \mathrm{~cm}$ below the surface. The experimental plot was on light sandy soil with a low content of humus.

It turned out that the number of mites and also the number of species of these ani-

Table 9 Average number of soil animals per apple leaf disc enclosed in $62.5 \mathrm{ml}$ sterile sand and inserted $5 \mathrm{~cm}$ below surface in soil of the field plot at Wageningen, 22 April4 June 1970

\begin{tabular}{lll}
\hline Animals & Coarse sand (fraction size $1-2 \mathrm{~mm}$ ) & $\begin{array}{l}\text { Fine sand } \\
\text { (fraction size } 0.2 \mathrm{~mm} \text { ) }\end{array}$
\end{tabular}

With leaf discs; $n=18$; for the nematodes $n=6$

$\begin{array}{lcc}\text { Enchytraeidae } & 3.7 & 2.3 \\ \text { Nematoda } & 196 & 600 \\ \text { Pauropoda } & 0.5 & 0.2 \\ \text { Scutigerella } & 0.05 & 0 \\ \text { Collembola } & 2.6 & 5 \\ \text { Acari } & 8.8(2.4 \text { Gamasides }) & 2.5(0.2 \text { Gamasides })\end{array}$

Without leaf discs. Check samples $n=6 *$

$\begin{array}{lll}\text { Collembola } & 0.3 & 4 \\ \text { Acari } & 2.2 & 2.4 \\ \text { Pauropoda } & 0.3 & 0\end{array}$

* Enchytraeidae and Nematoda not investigated. 
mals was considerably larger in the samples with coarse sand (Table 9). The number of Pauropoda and Enchytraeidae was also greater. The number of springtails was smaller. But as biomass the content of springtails was higher. The size of the species occurring in the coarse sand was larger than those in the fine sand. The mites as well as the springtails were represented as small species or as juveniles of larger species. There were very few predacious mites, Mesostigmata. There were many more nematodes in the samples with fine sand. The relatively small number of predacious mites perhaps allowed larger populations of nematodes to become established. A few mites and springtails were found in the cylinders with sand, without a leaf disc. These cylinders were used as controls. The organic matter of the enclosed leaf discs of course attracted the animals found from adjacent soil.

The counts of mites and springtails are presumably largely dependent on the microflora, which in turn is dependent on soil structure and on the type and amount of organic matter in the soil. Indirectly, therefore, the type of vegetation affects the counts of mites and springtails.

\section{Reference}

Bakermans, W. A. P. \& C. T. de Wit, 1970. Crop husbandry on naturally compacted soils. Neth. J. agric. Sci. $18: 225-245$. 